\title{
As montanhas nevadas do Tibete: Tradução da poesia de Tsering Kyi
}

Thais Giammarco

Resumo: Este breve artigo descreve algumas das questões envolvidas na tradução de um poema tibetano para o português a partir de sua versão em inglês, comentando suas especificidades e justificando escolhas com base em premissas da tradução do texto literário em geral e, em especial, de poesia, com base na teoria de Paulo Henriques Britto.

Palavras-chave: Tsering Kyi; Paulo Henriques Britto; Montanhas Nevadas; samsara; poesia tibetana

\begin{abstract}
This brief article describes some of the questions involved in the translation of a Tibetan poem into Portuguese from its English version, commenting on its specificities and justifying choices based on premises of the translation of the literary text in general and, in particular, of poetry, with the support of Paulo Henriques Britto's theory.
\end{abstract}

Keywords: Tsering Kyi; Paulo Henriques Britto; Snow Mountains; samsara; Tibetan poetry 


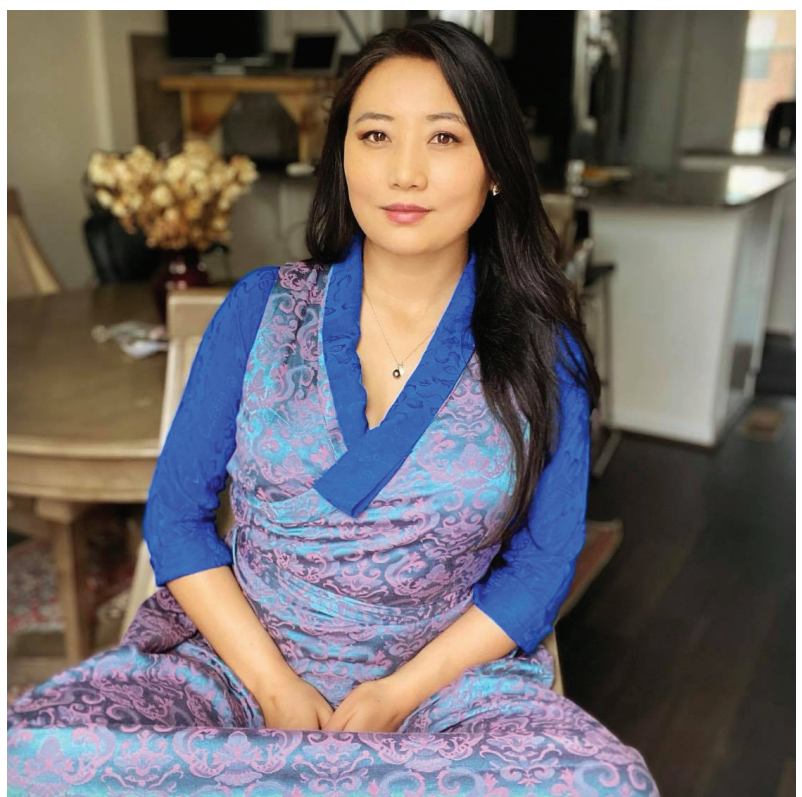

Traduzir "O Samsara das Montanhas Nevadas" foi como uma viagem ao Tibete. Sendo um poema que trata de uma das características mais expressivas do país, as montanhas mais altas do mundo com picos cobertos de neve do Planalto Tibetano, e que se refere a diversos elementos culturais e geográficos, fez-se necessário realizar uma pesquisa detalhada para tomar decisões na tradução deste poema tão belo quanto difícil para o português. Esta pesquisa se desenrolou desde o contato com o tradutor do poema tibetano para o inglês com o objetivo de esclarecer dúvidas até a consulta de imagens e vídeos dos locais mencionados no poema para compor uma imagem mental deste imponente cenário, dada a força de sua representatividade no poema.

Adotamos o pressuposto teórico de que um texto literário deve ter os elementos que o caracterizam como tal preservados em sua tradução, de acordo com Britto (2012). Ainda de acordo com o teórico:

No caso do texto poético, o caso-limite da literariedade, podem ter importância igual ou ainda maior o som das palavras, o número de sílabas, a distribuição de acentos nelas, as vogais e consoantes que aparecem em determinadas posições de cada palavra; além disso, também pode ser relevante 
a aparência do texto no papel, a começar pela localização dos cortes que separam um verso do outro. (BRITTO, 2012, Kindle posição 599 de 2156)

Visto que o poema "The Samsara of Snow Mountains", de Tsering Kyi, foi escrito em versos livres, foram mantidos os cortes que separam um verso de outro e houve um esforço na tentativa de manter uma correspondência sonora e em termos de números de sílabas na maior parte dos versos.

Em relação a questões semânticas, a primeira dificuldade surgiu já no título: "samsara" é uma palavra do sânscrito, que significa "perambulação" ou "mundo", e se refere ao ciclo incessante de morte e renascimento que o ser humano experimenta e do qual não consegue se libertar a não ser atingindo a iluminação. Portanto, algo negativo, com o qual se almeja romper. No entanto, no título e no último verso deste poema, a conotação do termo soava diferente da conhecida: parecia sugerir algo positivo. Por meio de repetidas leituras do poema e com uma consulta à poeta Tsering Kyi por intermédio do tradutor do tibetano para o inglês, pudemos chegar à conclusão de que neste poema o "samsara" se relaciona à estabilidade das montanhas, presentes no mesmo local há milhares de anos, inabaláveis pelo tempo e pela ação humana. A constância das montanhas em oposição à inconstância, fragilidade e efemeridade da vida humana, e, ainda assim, abrigando-a, servindo-lhe de domićlio e inspiração de conduta, se revelaram os eixos temáticos centrais do poema. Optamos por manter o termo em sânscrito com uma nota explicativa, visto que é utilizado também em português especialmente em contextos relacionados principalmente ao budismo, mas também a outras religiões orientais, como o hinduísmo e o jainismo.

Outro termo sem equivalentes tanto em inglês quanto em português é "sangsol", e se refere ao ritual de queimar galhos de zimbro como oferenda aos deuses e a seres de todos os reinos budistas. Neste poema, o ritual está relacionado aos ancestrais da poeta - e, provavelmente, por extensão, de todos os seres humanos, por isso optamos por "nossos pais" na tradução - aos quais a estabilidade das montanhas é atribuída. Portanto, vemos aqui mais um elemento religioso ligado à tradição oriental; devido a ações virtuosas de antepassados, tem-se uma dádiva no tempo presente: o caráter imutável das montanhas do Planalto Tibetano.

São citados ao longo do poema diversos epítetos relacionados ao Tibete: Snowland (Terra das Neves), Pure Land (Terra Pura), White Castle (Castelo Branco). Com relação a este último, optamos por eliminar as iniciais em maiúsculas e inverter a ordem dos termos em português, bem como por fazer uma tradução menos literal, resultando em "níveo castelo", pelo fato de "castelo branco" possuir outra 
relação semântica na língua portuguesa associada ao cenário político brasileiro, em especial se o termo for iniciado por maiúsculas. Vale realçar que as próprias montanhas nevadas iniciam-se com maiúsculas no poema porque identificam o Planalto Tibetano. Nesta estrofe, houve uma perda: o verso "A Terra das Neves, unida à minha sombra compõe um magnífico e níveo castelo" era, no original, "Snowland-bonded with my shadow makes a magnificent White Castle.". A poeta faz uso de um epíteto relacionado ao país (Snowland/Terra das Neves) seguido de uma referência à fusão desta terra com sua própria sombra resultando em um "White Castle", sugerindo que o alvor da paisagem é capaz de neutralizar a escuridão do eu-lírico. Por outro lado, do ponto de vista formal, o efeito sonoro advindo do jogo de palavras entre "neve" e "níveo" não deixa de ser interessante. Desta forma, embora o contraste entre o branco da neve, que sugere pureza e a perfeição da natureza, e o tom escuro associado à sombra e à imperfeição humanas, fique enfraquecido na tradução, há uma compensação com o paralelismo de outros termos, corroborando a tese de Britto (2012) de que perdas, ganhos e compensações são inevitáveis no processo da tradução.

O estilo de Tsering Kyi é bastante descritivo, no entanto, em duas estrofes do poema a serem discutidas adiante, torna-se um pouco mais sugestivo. De qualquer forma, o pressuposto teórico de Britto (2012) também foi seguido nestes casos.

Não se trata, portanto, de produzir um texto que apenas contenha as mesmas informações que o original; trata-se, sim, de produzir um texto que provoque no leitor um efeito de literariedade - um efeito estético, portanto - de tal modo análogo ao produzido pelo original que o leitor da tradução possa afirmar, sem mentir, que leu o original. (BRITTO, 2012, Kindle posição 599 de 2156)

As estrofes em questão, e que ocorrem no poema exatamente nesta sequência, são as seguintes:

"People say - your lap existence is called the life of ignorant laymen People say - your raised pretty horses and sheep are mixed with forgotten livestock.

However, when those who have orbited the moon discuss the snow mountains and meadows when for thousands of years the red-faced people ${ }^{3}$ have known their beauty in their mind calling this the Pure Land cannot be mere ramblings of a fool, how could it be!" 
A primeira delas, mais hermética, e também mais permeada de traços culturais configurou um desafio maior na tradução. O termo "lap existence" não foi encontrado nas pesquisas, sendo elucidado pelo tradutor do tibetano para o inglês, e definido como uma tradução literal com o sentido, em suas palavras, de "a hand-to-mouth existence". Sendo assim, faz referência à precariedade material da vida do povo tibetano, em situação de extrema insegurança e provisoriedade, sem poder contar com mais que o essencial para cada momento, mas tangencia ainda o conceito budista de desapego. "Ignorant laymen", que o tradutor sugeriu interpretar como "countrymen" relaciona-se também com o próximo verso e, por oposição, com a estrofe seguinte, e refere-se ao estereótipo dos tibetanos como um povo inferior, que a poeta refuta de maneira sutil e levemente irônica na estrofe seguinte. No próximo verso, há referência ao caráter rural do país com a alusão aos animais que se confundem, sejam de criações ou selvagens, uma suave referência à implacabilidade da vida para com todos os seres humanos, instruídos e cosmompolitas ("those who have orbited the moon") ou não. Todavia, na segunda estrofe, a poeta contrapõe tal característica à sabedoria tibetana advinda da conexão com a terra e com a sua terra, por eles chamada Terra Pura e com uma espiritualidade madura, base do povo tibetano, e sugere que, para isso, não é necessário conhecimento científico ou de qualquer outra espécie além de uma profunda relação de experiência com a terra, que este povo vem cultivando há milhares de anos. Há aqui também a referência cultural aos tibetanos como "caras vermelhas" devido ao efeito do sol e do frio das montanhas sobre sua pele, avermelhando suas bochechas.

Outra questão digna de nota foi a tradução da interjeição "how could it be?", que aparece pela primeira vez no verso "Arising in illusions and appearing in dreams of beautiful romanticism, how could it be!" ("Surgindo em miragens e aparecendo em sonhos da mais bela fantasia, de que outro modo seria?"). Um diálogo indireto com a poeta elucidou uma referência ao fato de a beleza das montanhas ser tão intangível que não se pode crer real. Ao final da estrofe seguinte, esta interjeição reaparece, porém ligada a outro referencial. Agora, para manter o paralelismo formal com a primeira ocorrência, optamos por repeti-la no presente simples ("como pode ser?") e não no futuro do pretérito. Contudo, como estratégia de compensação (Britto, 2012), utilizamos o futuro do pretérito em um ponto anterior do mesmo verso em "não poderia ser apenas o mero delírio de um tolo", quando no original temos "cannot be mere ramblings of a fool" para manter a função semântica deste verbo modal. 
"However, when those who have orbited the moon discuss the snow mountains and meadows when for thousands of years the red-faced people have known their beauty in their mind calling this the Pure Land cannot be mere ramblings of a fool, how could it be!"

"Entretanto, quando aqueles que orbitaram a lua falam sobre montanhas nevadas e prados sendo que há milhares de anos os caras-vermelhas conhecem de cor sua beleza chamar este solo de Terra Pura não poderia ser apenas o mero delírio de um tolo, como pode ser?"

As referências geográficas da estrofe seguinte são bastante interessantes: o rio Yarlung Tsangpo, que se torna o Brahmaputra na Índia, é o mais longo do Tibete, e forma um dos cânions mais profundos do mundo. É válido ressaltar que muitos rios nascem nas montanhas do Planalto Tibetano (daí as "águas altivas"/"high water") e são responsáveis pelo abastecimento hídrico de grande parte da Ásia.

Com relação aos nomes dos rios, em inglês trata-se apenas de Ma, Dri e Za, visto que a palavra "chu" significa "rio" em chinês. Mas em português, os nomes mantêm o sufixo "chu”, sendo denominados Machu, Drichu e Zachu.

Finalmente, nas duas últimas estrofes, surge a intrigante simbologia do abutre e cabe destacar que este animal é considerado sagrado no Tibete, pois se alimenta dos restos de outros animais mortos, abundantes nas montanhas, onde o acesso e, consequentemente, a remoção, é difícil. Portanto, não fosse pela ação destas aves, os cadáveres de animais poluiriam as águas que abastecem grande parte do continente.

Desta forma, como destaca Britto (2012), tentamos realizar um equilíbrio entre perdas e ganhos por meio de compensações mantendo a literariedade do poema e as características que o definem como tal.

Sobre a poeta: Tsering Kyi Gangsangtsang nasceu no leste do Tibete e refugiou-se na Índia em 1999. Recebeu o título de "Miss Tibete" em 2003 e, desde então, tem viajado para vários países como embaixadora da causa tibetana. Em 2009, foi eleita membro executivo principal da Associação de Mulheres Tibetanas. Compõe sua poesia em tibetano e tem diversos livros publicados. Várias letras de canções de sua autoria foram musicadas e são conhecidas no Tibete. Em 2007, seu blogue foi considerado o segundo mais lido do Tibete. Atualmente, trabalha para a organização Voice of America, em Washington, nos Estados Unidos. 


\section{O poema original em língua Tibetana}

ज्ञे चरिषाएता ये।

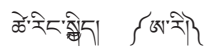

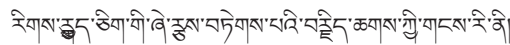

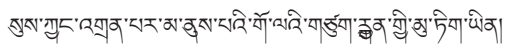

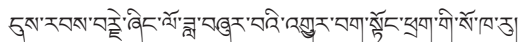

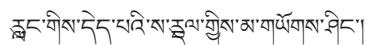

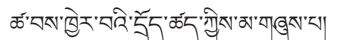

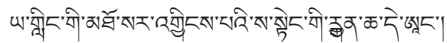

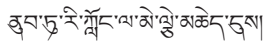

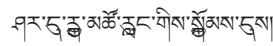

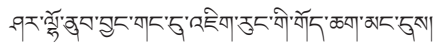

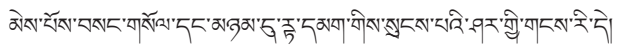

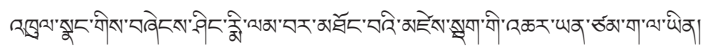

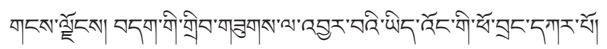

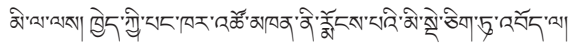

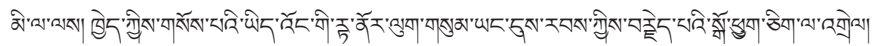

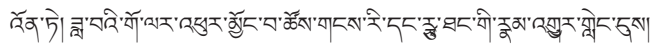

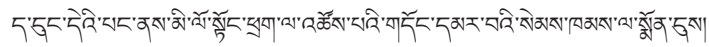

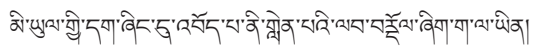

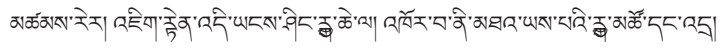

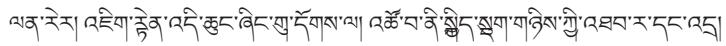

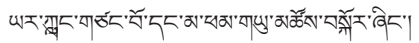

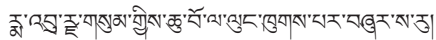

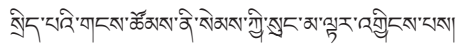

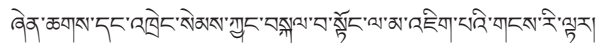

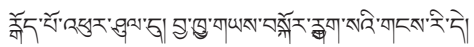

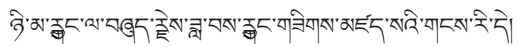

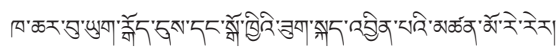

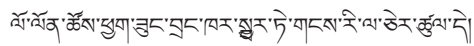

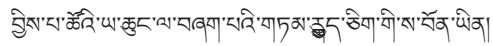

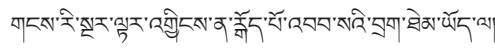

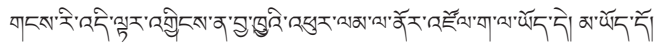

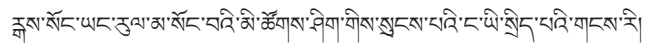

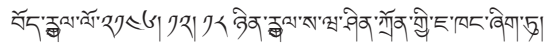




\title{
O poema em inglês (tradução de Lhakpa) SAMSARA $^{1}$ OF SNOW MOUNTAINS
}

\author{
-Tsering Kyi (translated by Lhakpa)
}

The lovely majestic Snow Mountains raised on deep ancestral roots are

the unmatched crown pearls of the planet Centuries have passed and years and months have melted through a thousand teeth of time

but they are uncovered by the windswept dust unmelted by the warming heat waves.

On the peak of Asia and jewel on top of the world, they stand tall

When flames burn from the center of mountains in the north

when ocean storms stir in the east

when fearsome calamities abound the north, south, east and west

protected with sangsol ${ }^{2}$ by the cavalry of my forefathers, the Snow Mountains stand

Arising in illusions and appearing in dreams of beautiful romanticism, how could it be! Snowland-bonded with my shadow makes a magnificent White castle.

People say- your lap existence is called the life of ignorant laymen

People say- your raised pretty horses and sheep are mixed with forgotten livestock.

However, when those who have orbited the moon discuss the snow mountains and meadows

when for thousands of years the red-faced people ${ }^{3}$ have known their beauty in their mind

calling this the Pure Land cannot be mere ramblings of a fool, how could it be!

Sometimes, this land's vast forests, its surroundings are endless like the ocean.

At times, this land is small and confined, life is a struggle between happiness and suffering.

1 Samsara is the Buddhist concept of earthly existence for human beings. We come and go, and our lives are not permanent, but the Samsara itself is unchanging. Here, the poet uses the word to convey the indomitable nature of the mountains, and the land as a place of home for this life. Tibet is often called the Land of Snow.

2 Sangsol is a purification ritual from the native Bon religion of Tibet, also widely practised later by the Buddhists. It involves the burning of juniper and pine leaves mixed with butter and barley flour as offering to the mountain spirits/gods.

3 Red-faced people are what Tibetans call themselves as their cheeks get red when bitten by the sun. 
The Yarlung ${ }^{4}$ river and lake Mapham Yutso ${ }^{5}$ encircle where great waters of the $\mathrm{Ma},{ }^{6} \mathrm{Dri}^{7}$ and $\mathrm{Za}^{8}$ flow throughout the country This samsara of snow mass is like a fortress for the mind fearless of attachment and clinging mind ${ }^{9}$ for eons like the Snow Mountains.

When vultures leave, birds flock to circle east to these Snow Mountains the sun sets far away and the moon gazes wide in these Snow Mountains When rain and sleet and snowstorms occur and when the guard dogs howl in the night the young ones press their palms against the chests and stare at the Snow Mountains. This is the youth leaving the seeds of their stories at the high water.

If the Snow Mountains stand as before, there will be rocky steps for vultures to land If they stand like this, how can the birds miss their flight's path? 'They would not. These mountains may age but they won't be ruined, protected by my ancestors, My samsara of Snow Mountains.

\section{A tradução do poema em português}

\section{O SAMSARA ${ }^{10}$ DAS MONTANHAS NEVADAS}

Erguendo-se sobre profundas raízes ancestrais, as majestosas Montanhas Nevadas são a incomparável coroa de pérolas do planeta

Séculos se passaram, e anos e meses derreteram em meio aos infinitos dentes do tempo no entanto elas seguem intocadas pela poeira do vento inabaladas pelas ondas de calor

4 The Yarlung Tsangpo is the most dominant river in central Tibet. It's called the Brahmaputra in India.

5 The Mapham Yutso is the Tibetan name for the sacred lake Manasarovar around Mt. Kailash.

6 The Machu river in Tibet, called the Yellow river in China.

7 The Drichu river in Tibet, called the Yangtse river in China.

8 The Zachu river in Tibet, called the Mekong river in South East Asia.

9 Attachment and clinging mind are conditions of mind described in Buddhism to represent desire and greed that keeps mankind in Samsara.

10 Samsara é o conceito budista de uma vida mundana para os seres humanos, que vêm e vão. Nossas vidas são efêmeras, mas o Samsara não muda. Aqui, a poeta usa esta palavra para se referir à natureza imutável das montanhas, e à terra como uma residência para essa vida. 
No cimo da Ásia, resistem, joias cravadas no topo do mundo

Quando o ventre das montanhas do norte arde em chamas

quando as procelas do leste se alvoroçam

e calamidades medonhas transbordam a norte, sul, leste e oeste

sob a proteção do sangsol ${ }^{11}$ do exército de nossos pais, sustêm-se as Montanhas Nevadas

Surgindo em miragens e aparecendo em sonhos da mais bela fantasia, como pode ser?

A Terra das Neves, unida à minha sombra compõe um magnífico e níveo castelo

Dizem que uma existência frugal é a vida do ser humano insciente

Dizem que os belos rebanhos de cavalos e ovelhas misturam-se às manadas esquecidas

Entretanto, quando aqueles que orbitaram a lua falam sobre montanhas nevadas e prados

sendo que há milhares de anos os caras-vermelhas ${ }^{12}$ conhecem de cor sua beleza chamar este solo de Terra Pura não poderia ser apenas o mero delírio de um tolo, como pode ser?

Às vezes, as vastas florestas desta terra e seus arredores não têm fim, como o oceano. Outras vezes, este solo é pequeno e confinado, e a vida é uma luta entre tormento e ventura.

O rio Yarlung e o lago Mapham Yutso fazem um círculo

onde as grandes águas do Machu, do Drichu, e do Zachu correm, cruzando o país

Este samsara de neve maciça é uma fortaleza para a mente

a mente que não teme o apego e a ganância há eras, feito as Montanhas Nevadas.

Quando partem os abutres, reúnem-se os pássaros a voar para o leste rumo às Montanhas Nevadas

o sol se põe ao longe e a lua contempla as Montanhas Nevadas

11 Sangsol é um ritual de purificação oriundo da religião Bon, nativa do Tibete, que passou a ser muito utilizado pelos budistas. Trata-se de queimar folhas de zimbro e pinheiro misturadas a manteiga e farinha de cevada como oferenda para os deuses e espíritos das montanhas.

12 Os tibetanos referem-se a si mesmos como "caras-vermelhas", pois suas bochechas ficam vermelhas quando em contato com o sol nas montanhas. 
Quando há chuva e granizo e nevasca, e os cães de guarda uivam noite adentro os jovens levam a mão ao peito e contemplam as Montanhas Nevadas.

A juventude semeia sua história em águas altivas.

Se as Montanhas Nevadas continuarem como antes, haverá patamares de pedra onde os abutres possam pousar

Se continuarem assim, como podem os pássaros perder seus caminhos? Não podem! Ainda que envelheçam, essas montanhas não haverão de ruir, protegidas por meus antepassados,

O meu samsara das Montanhas Nevadas.

Lhakpa nasceu no Tibete e exilou-se nos Estados Unidos, onde atualmente trabalha como tradutor e escritor.

Thais Giammarco é Mestre em Teoria e História Literária (Unicamp/2009), com pesquisa e tradução da peça “Dido, Queen of Carthage”, de Christopher Marlowe. Pós-graduada pelo programa de Especialização do CITRAT-USP (2005), interessa-se em especial por projetos de tradução relacionados à poesia e à literatura feita por mulheres. Traduziu recentemente poemas de Lorine Niedecker e "The Yellow Wallpaper", de Charlotte Perkins Gilman, ainda sem publicação. Atualmente, cursa o Programa Formativo de Tradutores Literários oferecido pela Casa Guilherme de Almeida, em São Paulo. 